\title{
Isolation and Preliminary Molecular Characterization of Novel Anaerobic Microbial Species from the Interface Between Zaopei (Fermented Grains) and the Bottom Pit Mud
}

\author{
Ying HAN ${ }^{1}$, Hong-kui HE${ }^{2, a, *}$, Hang $\mathrm{DU}^{1}$, Run-jie $\mathrm{CAO}^{2}$, Hai-ning \\ NING ${ }^{1}$, Zhi-hui TANG ${ }^{2}$, An-jun LI ${ }^{2}$ and Zhi-zhou ZHANG ${ }^{1,3, b^{*}}$ \\ ${ }^{1}$ School of Marine Science and Technology, Marine anti-fouling Engineering \\ Technology Center of Shandong Province, Harbin Institute of Technology, Harbin, \\ China 150006 \\ ${ }^{2}$ The Anhui GuJing Tribute Liquor Ltd, Bozhou, Anhui, China 236800 \\ ${ }^{3}$ Shandong Gredmedic Co., Ltd., Weihai, China 264209 \\ ahongkui896@163.com, bzhangzzbiox@hitwh.edu.cn \\ ${ }^{*}$ Corresponding authors
}

Keywords: Anaerobic microbe, Liquor, Pit mud, Zaopei, Interface.

\begin{abstract}
Strong-aroma type liquor occupies over $70 \%$ of Chinese liquor market, but the namelist of key microbes responsible for liquor flavor is still vague. Lots of data indicate that the interface between the bottom pit mud and Zaopei (fermented grains) plays an important role for aroma molecule production, so isolation and characterization of anaerobic microbial species from the interface is of great importance. In this study, a specific culturing medium was prepared with the bottom pit mud and Zaopei materials to isolate over a hundred colonies, some of which were characterized mainly as Clostridia and Lactobacillus microbes using the full-length 16S rDNA sequencing; but not all of them can be classified into species at high confidence levels, suggestive of novel anaerobic species.
\end{abstract}

\section{Introduction}

Traditional Chinese alcoholic liquor is typically classified into five categories based on aroma characteristics: soy sauce aroma, strong aroma, light aroma, rice aroma, and miscellaneous. The representative liquor brands are Maotai and Langjiu [1,2] for soy sauce aroma type, Luzhou [2], Jiannanchun [3], Wuliangye [3], GujingTribute [4] and Yanghe [5] for strong aroma type; Fen [2] for light aroma type, and Guilin Sanhua [6] for rice aroma type. It is regarded that strong aroma, light aroma, soy sauce aroma and rice aroma are four basic types of Chinese liquor while all other types are derived from them. Examples for the miscellaneous types are combined aroma, herbaceous aroma, sesame aroma, Feng aroma, Te aroma, and fermented-soya-beans aroma; and their typical representatives are Baiyunbian Liquor [7], Dong Liquor [8], Jingzhi Baigan [9], Xifeng [10], SiTe [11], and Yubingshao [12], respectively. The total sales volume of Chinese liquor was 804 billion dollars in 2015 [13].

Among all types of Chinese liquor, strong-aroma type occupies a large percentage of the whole production. However, key microbial species responsible for aroma style formation are still unclear. So isolation and characterization of those individual strains, especially anaerobic microbial species at the interface between pit mud and Zaopei plus the yellow water (the two-phase liquid with organic matter and inorganic substance, 
aggregates during the fermentation and falls down on the pit bottom; The yellow water is a place where lots of aroma molecules are presumably synthesized), are still of great significance. The reasons include at least the following three parts: (1) It has been a practical experience in the strong-aroma alcohol industry that good liquor only comes from good-quality pit mud. So the interaction between the bottom pit mud and fermented grains or Zaopei is a correct place to locate key microbes. (2) Strong-aroma liquor is produced by solid-state fermentation that means there are not much mass exchange between grains and the surrounding pit mud soil. The pit bottom is a place where Zaopei, pit mud soil and yellow water interact with each other and is most likely the location for main (at least some) key aroma molecules to be synthesized. (3) Few studies have specifically been focused on the above interface in the context of anaerobic microbe isolation and molecular characterization.

In this study, pit mud and Zaopei materials were employed to be the main part of the culturing medium to isolate colonies from the Zaopei-pit mud surface, or in detail, the Zaopei-yellow water-pit mud soil interface. Colonies were cultured in an anaerobic workstation, recorded with multiple morphological parameters, and statistically classified. The representative colonies were subjected to genome DNA extraction, full-length 16S rDNA amplification and Sanger-sequencing. The results turned out that most of the colonies belong to Clostridia and Lactobacillus, but some of them were still hard to be classified to the species level.

\section{Materials and Methods}

\section{Medium Preparation}

The $60 \mathrm{~g}$ pit mud plus $60 \mathrm{~g}$ Zaopei were suspended in $600 \mathrm{ml}$ sterile distilled water, followed by $10 \mathrm{~min}$ centrifugation at $15000 \mathrm{r} / \mathrm{min}$. $500 \mathrm{ml}$ supernatant was then mixed with glucose $7 \mathrm{~g}$, beef extract $1 \mathrm{~g}$, peptone $2 \mathrm{~g}, \mathrm{NaCl} 2 \mathrm{~g}$, yeast extract $0.5 \mathrm{~g}, \mathrm{MgCl} 2(1 \mathrm{M})$ $21 \mu 1, \mathrm{~K} 2 \mathrm{HPO} 40.75 \mathrm{~g}$, FeSO4•7H2O 0.05g, L-cysteine $0.25 \mathrm{~g}$, and agar $10 \mathrm{~g}$. After $30 \mathrm{~min}$ autoclaving, the medium was plated in petri dishes within the A35 anaerobic workstation.

\section{Microbe Isolation and Cultivation}

Microbe stock solution was made by mixing $1 \mathrm{~g}$ pit mud into $1 \mathrm{ml}$ yellow water (fresh). $5 \mu 1$ the above stock solution plus $495 \mu 1$ sterile distilled water was then used to inoculate the medium plate and cultured at $32^{\circ} \mathrm{C}$ in the workstation with the gas condition $\left(\mathrm{N}_{2}: \mathrm{O}_{2}: \mathrm{CO}_{2}=8: 1: 1\right)$ for 4 days. The 187 colonies were picked up into eppendorf tubes and stored at $-80^{\circ} \mathrm{C}$ for further use.

\section{Molecular Characterization of Individual Colonies}

Genomic DNA was extracted from individual coloniess using Solarbio D2600 kit. Each $20 \mathrm{mg}$ or around colony sample generated 100ul genome DNA. The 16s rDNA amplification was undertaken using universal primers 27F (5'- AGA GTT TGA TCC TGG CTC AG-3') and 1492R (5'TAC GGY TAC CTT GTT ACG ACT T3'). The PCR system had a total volume of $12 \mu \mathrm{L}$ consisting of $1 \mu \mathrm{L}$ of template DNA, 6 ul of NPK02 $2 \times$ buffer, $0.8 \mu \mathrm{L}$ of each primer $(2 \mu \mathrm{M}), 0.2 \mathrm{ul}$ Taq DNA polymerase (5U/ul), and 3.2 $\mu \mathrm{L}$ of distilled water. In the negative control, the template DNA was replaced by the same volume of water. The reactions started with an initial denaturing step at $95^{\circ} \mathrm{C}$ for $5 \mathrm{~min}$, followed by 34 cycles of $95^{\circ} \mathrm{C}$ for $30 \mathrm{~s}, 60^{\circ} \mathrm{C}$ for $60 \mathrm{~s}$, and $72^{\circ} \mathrm{C}$ for $60 \mathrm{~s}$, and were 
appended with a 4 min elongation step at $72^{\circ} \mathrm{C}$. Amplified target bands (about 1500bp) were gel-purified using Sangon SanPrep kit (Cat\#: SK8132). Purified DNA was then subjected to Sanger sequencing using both $27 \mathrm{~F}$ and $1492 \mathrm{R}$. The raw sequences were assemblied by CExpress and edited by EditSeq to make sure of correct orientation. Successfully assemblied DNA was subjected to Basic Local Alignment Search Tool (BLAST) analysis at the National Center for Biotechnology Information (NCBI) database (www.ncbi.nlm.nih.gov) in order to get species-level taxonomic information. The same sequences were also input in the RDP database for further classification.

\section{Results and Discussion}

\section{Isolation of Anaerobic Microbes}

In this study, the total 187 anaerobic colonies were collected (detailed data not shown) and classified according to their morphological parameters. 4-day incubation brought many gas bubbles around some colonies (Fig.1); those colonies may produce either $\mathrm{CO}_{2}$, $\mathrm{H}_{2}$ or $\mathrm{CH}_{3}$.

\section{Sequencing of Isolated Colonies}

Twenty two representative colonies were subjected to further molecular characterization. The sequencing and BLAST results were summarized in Table 1. Some colonies were not as easy as other ones for genomic DNA extraction, seen in Fig.2 in which some 16S rDNA amplification results were demonstrated.

\section{Functional Implications of the Isolated Microbes}

Because the Table 1 didn't provide species-level information for all colonies, it is hard to compare these microbes with those already deciphered early time in the GujingTribute pit mud, Daqu and Zaopei [14-16].Table 1 also confirmed that the full length 16S rDNA is insufficient to locate the taxonomic positions for species-level discrimination. However, the released limitation on species-level information is already of great interest. For example, Clostridium tyrobutyricum is a strain that produces butyric acid, acetic acid and hydrogen, and undoubtedly plays an important role in aroma molecule synthesis around the mentioned interface.

Previous study of GujingTribute pit mud and Zaopei microbial compositions released that Lactobacillus acetotolerans was the most dominant species in Zaopei and also frequently one of the most dominant species in the pit mud. Consistently, this study found some Lactobacillus acetotolerans colonies (Table 1), suggesting that the anaerobic conditions used in this study may be appropriate for Lactobacillus acetotolerans to grow. Later on it is essential to measure the gas components (Fig.1) in order to prepare a better gas conditions for the growth of those in vivo dominant species. Some of the sequenced colonies were found as Lactobacillus homohiochii (Table1), a strain that was reported to possess proteolytic activity and biogenic amines production in a Portuguese traditional dry fermented sausage [17].

Anaerobic microbes are hard to cultivate in general. There are several lines of approaches to cultivate those unknown anaerobic microbes, and the main technological outlines are described below. (a) Medium component improvement [18-21]: the main character of this approach is to add metabolic components or mixtures extracted from the original niche that supports the growth of target microbes; (b) Cultivation protocol improvement [22]: adjustment of the gas ratio may significantly increase the chance for some microbes to grow. Button [22] employed the dilution approach to incubate some 
type of marine microbes using sterile sea water and obtained decent results. (c)In situ cultivation: several lines of this type of method have been set up [23-24]. For example, Kaeberlein et al [23] designed a diffusion chamber that allowed the growth of previously uncultivated microorganisms in a simulated natural environment. (d)Encapsulation method: Ben-Dov et al [25] presented an innovative method for cultivating microorganisms by encapsulating them within agar spheres, which are then encased in a polysulfonic polymeric membrane and incubated in a simulated or natural environment and obtained plenty of novel microorganisms. In this study, pit mud and Zaopei plus yellow water were sterilized and used as supplementary components in the medium and got satisfactory results.

\section{Clostridium and Lactobacillus may directly interact on the interface}

There are many evidences that Clostridium microbes are responsible for synthesis of a batch of aroma or pre-aroma molecule, such as butyric acid, caproic acid and fatty acids. However, Lactobacillus seems play different roles. Some reports indicated Lactobacillus acetotolerans and Lactobacillus brevis was a major contaminant of spoiled beer [26-28], and Lactobacillus brevis was also declared as the potential cause for Chinese rice wine spoilage [28]. Several other studies on Chinese strong-aroma liquor [29-31] provided evidences that the most dominant species in Zaopei (fermented grains) often belongs to Lactobacillus, though this is not the case for Maotai [32]. So functional interaction (especially on the interface) between these two genera is of great value to investigate in the future.

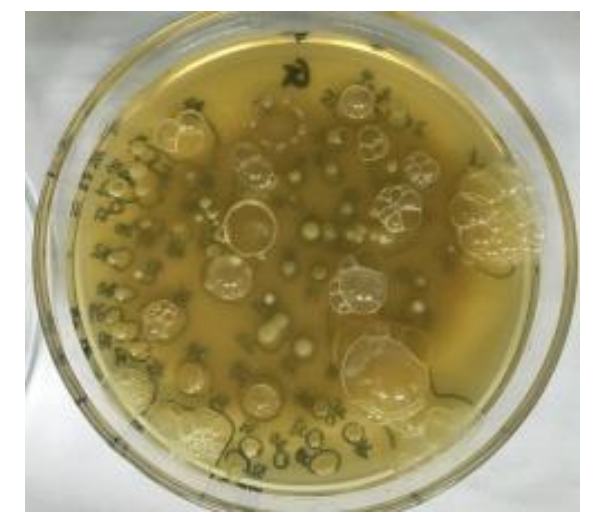

Figure 1. Four-day incubation of anaerobic microbes isolated from the pit mud-Zaopei-yellow water interface.

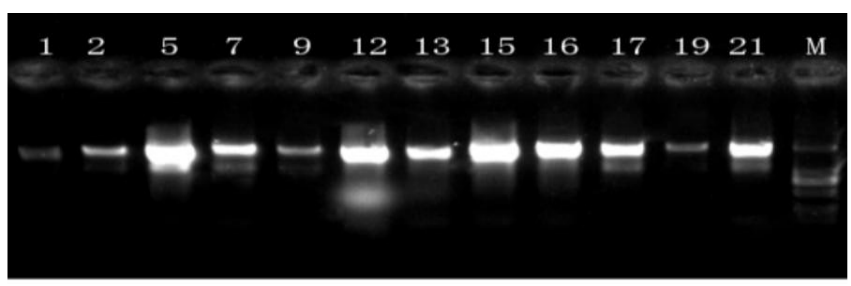

Figure 2. Full-length 16S rDNA amplification of some colonies. M: DL2000 DNA marker (2000, $1000,750,500$ and 100bp) 
Table 1. Example colonies characterized by BLAST analysis

\begin{tabular}{|c|c|c|c|c|}
\hline Colony No. & Description & Query cover & Identy & Accession \\
\hline \multirow[t]{2}{*}{$1^{*}$} & Clostridium tyrobutyricum strain W428,complete genome & $100 \%$ & $98 \%$ & СР016280.1 \\
\hline & Clostridium tyrobutyricum strain KCTC 5387 ,complete genome & $99 \%$ & $99 \%$ & СР014170.1 \\
\hline \multirow[t]{2}{*}{2} & Clostridium tyrobutyricum strain W428, complete genome & $98 \%$ & $99 \%$ & СР016280.1 \\
\hline & Clostridium tyrobutyricum strain KCTC 5387, complete genome & $99 \%$ & $99 \%$ & СР014170.1 \\
\hline 3 & Clostridium tyrobutyricum strain W428, complete genome & $97 \%$ & $95 \%$ & CP016280.1 \\
\hline $4^{*}$ & Clostridium tyrobutyricum strain W428, complete genome & $98 \%$ & $96 \%$ & СР016280.1 \\
\hline \multirow[t]{2}{*}{$5^{*}$} & Clostridium tyrobutyricum strain W428,complete genome & $97 \%$ & $98 \%$ & СР016280.1 \\
\hline & Clostridium tyrobutyricum strain KCTC 5387,complete genome & $99 \%$ & $99 \%$ & СР014170.1 \\
\hline 6 & Lactobacillus homohiochii strain JNLAB-5 16S ribosomal RNA gene,partial & $91 \%$ & $95 \%$ & KC336486.1 \\
\hline \multirow[t]{2}{*}{$7 *$} & Clostridium tyrobutyricum strain CT5 $16 \mathrm{~S}$ ribosomal RNA gene.partial & $98 \%$ & $100 \%$ & KP753673.1 \\
\hline & Clostridium tyrobutyricum strain KCTC 5387, complete genome & $98 \%$ & $99 \%$ & СР014170.1 \\
\hline $8^{*}$ & Uncultured Laclobacillus sp.gene for 16S rRNA.partial sequence,clone:CLZX10 & $84 \%$ & $94 \%$ & LC055569.1 \\
\hline \multirow[t]{2}{*}{$9^{*}$} & Clostridium tyrobutyricum strain W428,complete genome & $100 \%$ & $99 \%$ & СР016280.1 \\
\hline & Clostridium tyrobutyricum strain KCTC 5387, complete genome & $100 \%$ & $99 \%$ & СР014170.1 \\
\hline $10^{*}$ & Clostridium tyrobutyricum strain W428, complete genome & $94 \%$ & $96 \%$ & СР016280.1 \\
\hline $11^{*}$ & Clostridium tyrobutyricum strain SCTB 128 16S ribosomal RNA gene,partial & $93 \%$ & $89 \%$ & JN650293.1 \\
\hline \multirow[t]{2}{*}{12} & Clostridium tyrobutyricum strain $116 \mathrm{~S}$ ribosomal RNA gene, partial sequence & $98 \%$ & $97 \%$ & KF611978.1 \\
\hline & Clostridium tyrobutyricum strain W428,complete genome & $98 \%$ & $97 \%$ & СР016280.1 \\
\hline \multirow[t]{2}{*}{$13^{*}$} & Clostridium tyrobutyricum strain W428,complete genome & $98 \%$ & $99 \%$ & СР016280.1 \\
\hline & Clostridium tyrobutyricum strain KCTC 5387, complete genome & $98 \%$ & $99 \%$ & СР014170.1 \\
\hline 14 & Clostridium tyrobutyricum strain W428,complete genome & $93 \%$ & $96 \%$ & СР016280.1 \\
\hline \multirow[t]{2}{*}{15} & Lactobacillus acetotolerans gene for $16 \mathrm{~S}$ ribosomal RNA, partial sequence & $94 \%$ & $93 \%$ & LC202658.1 \\
\hline & Uncultured Lactobacillus sp.gene for 16S rRNA.partial sequence,clone:CXZX1 & $94 \%$ & $93 \%$ & LC055591.1 \\
\hline \multirow[t]{2}{*}{16} & Lactobacillus acetotolerans gene for $16 \mathrm{~S}$ ribosomal RNA, partial sequence & $99 \%$ & $99 \%$ & LC202658.1 \\
\hline & Uncultured Lactobacillus sp.gene for 16S rRNA.partial sequence,clone:CXZX1 & $99 \%$ & $99 \%$ & LC055591.1 \\
\hline \multirow[t]{2}{*}{17} & Clostridium tyrobutyricum strain W428,complete genome & $99 \%$ & $99 \%$ & СР016280.1 \\
\hline & Clostridium tyrobutyricum strain KCTC 5387,complete genome & $99 \%$ & $99 \%$ & СР014170.1 \\
\hline 18 & Lactobacillus acetotolerans gene for $16 \mathrm{~S}$ ribosomal RNA,partial & $92 \%$ & $96 \%$ & LC071813.1 \\
\hline \multirow[t]{2}{*}{19} & Lactobacillus acetotolerans gene for $16 \mathrm{~S}$ ribosomal RNA, partial sequence & $98 \%$ & $99 \%$ & LC202658.1 \\
\hline & Uncultured Lactobacillus sp.gene for 16S rRNA.partial sequence,clone:CXZX1 & $98 \%$ & $99 \%$ & LC055591.1 \\
\hline 20 & Uncultured Lactobacillus sp.gene for 16S rRNA.partial sequence,clone:CLZX10 & $89 \%$ & $96 \%$ & LC055569.1 \\
\hline \multirow[t]{2}{*}{21} & Lactobacillus acetotolerans strain NM122-2 16S ribosomal RNA gene, partial & $94 \%$ & $82 \%$ & HM218496.1 \\
\hline & Lactobacillus acetotolerans gene for $16 \mathrm{~S}$ ribosomal RNA, partial sequence & $94 \%$ & $82 \%$ & LC202658.1 \\
\hline 22 & Lactobacillus homohiochii strain JNLAB-5 16S ribosomal RNA gene,partial & $91 \%$ & $94 \%$ & KC336486.1 \\
\hline
\end{tabular}

*Note: colonies that displayed gas bubbles later on

\section{Summary}

In conclusion, this study combined the anaerobic cultivation facility and supplementary mixture from pit mud-Zaopei-yellow water in GujingTribute pit and successfully obtained a large number of bacteria, some of which were characterized by $16 \mathrm{~S}$ rDNA as Clostridium and Lactobacillus microbes. It is likely that some of them are novel 
bacterial strains or sub-strains not yet studied. What biological functions they undertake and how they interact with each other in the context of strong-aroma flavor determination are worthy of vigorous investigation in the future.

\section{Acknowledgement}

This study was supported by NSFC (No.31071170), GujingTribute fund (2016-1), GREDBIO (201401) and HIT fund (hitwh200904, 2016GSF115022).

\section{References}

[1] Wang, C.L., Shi, D.J. \& Gong, G.L. World J Microbiol Biotechnol. 24 (2008) 2183-2190.

[2] Zhang, L., Wu, C., Ding, X., Zheng, J. \& Zhou, R. World J Microbiol Biotechnol. 30 (2014) 3055-3063.

[3] Fan, W. \& Qian, M. C. J Agric Food Chem. 54 (2006) 2695-2704.

[4] Li, H.H. et al. J Food Sci Technol. 34(1) (2016) 55-65.

[5] Fan, W. \& Qian, M. C. Flavour Fragr J. 21 (2006) 333-342.

[6] Tang, Q.L. et al. Liquor Mak Sci Technol. 9 (2015) 8-11. (in Chinese)

[7] Xiong, X.M. et al. Liquor Mak Sci Technol. 4 (2016) 30-34. (in Chinese)

[8] Fan, W.L. et al. J Food Sci Biotechnol. 8 (2012) 810-819.

[9] Lao, A.G., Zhao, D.Y. \& Cao, J.Q. Liquor Mak. 36 (2009) 91-93. (in Chinese)

[10] Yan, Z.K. et al. Liquor Mak. 42(3) (2015) 36-41. (in Chinese)

[11] Yan, M.T. et al. Liquor Mak Sci Technol. 3 (2016) 57-60. (in Chinese)

[12] Yan, J. et al. Liquor Mak. 39(6) (2012) 32-35. (in Chinese)

[13] Song, S.Y. Liquor Mak Sci Technol. 6 (2016) 17-28. (in Chinese)

[14] Zhang, H.M. et al. Sci Technol Food Ind.13 (2014) 200-206, 228.

[15] Zhang, H.M. et al. Mod Food Sci Technol.30(4) (2014) 44-49.

[16] Zhang, H. et al. Mol Biotechnol. 58 (2016) 729-737.

[17] Pereira, C.I., Crespo M.T. \& Romão M.V. Int J Food Microbiol. 68(3) (2001)211-216.

[18] Jassen, P.H. et a1. Applied and Environmental Microbiology, 68(5) (2002) 2391-2396.

[19] Davis, K.E., Joseph S.J. \& Janssen P.H., et a1. Applied and Environmental Microbiology, 1(2) (2005) 826-834.

[20] Stevenson, B.S. et al. Appl Environ Microbiol,70 (2004) 4748-4755.

[21] Bruns, A., Cypionka, H. \& Overmann, J. Appl Environ Microbiol, 68(2002) 3978-3987.

[22] Button, D.K., Schut, F. \& Quang, P. Appl Environ Microbiol,59(3) (1993) $881-891$ 
[23] Kaeberlein, T., Lewis K. \& Epstein S.S. Science,296 (2002) 1127-1129

[24] Gavrish, E. et al. J Microbiol Methods, 72 (2008) 257-262

[25] Ben-Dov, E., Kramarsky-Winter, E. \& Kushmaro, A. FEMS Microbiology Ecology, 68(3) (2009) 363-371

[26] Liu, J. et al. Sci Rep. 6 (2016) 36753.

[27] Sakamoto, K. et al. J Bacteriol. 183 (2001) 5371-5375.

[28] Hong, X. et al. Sci Rep. 6 (2016) 26621.

[29] Ding, X.F. et al. World J Microbiol Biotechnol. 30 (2014) 605-612.

[30] Zheng, J. et al. Food Res Int. 54 (2013) 660-666.

[31] Zheng, J. et al. J Food Sci. 79 (2014) M2491-M2498.

[32] Wang, Q., Zhang, H., Liu, X. J Food Sci. 81 (2016) M1485-M1494. 